\title{
Cefdinir with Antacid and Metal Complexation and Investigation of Antimicrobial Activity, In-Vitro Demonstration
}

\author{
Md Shahidul Islam* and Md Abbul Motaleb Bhuiya \\ Department of pharmacy, University of Science and Technology Chittagong (USTC), Chattogram, Bangladeshy
}

*Corresponding author: Md Shahidul Islam, Department of pharmacy, University of Science and Technology Chittagong (USTC), Chattogram, Bangladesh

\begin{tabular}{|c|c|}
\hline ARTICLE INFO & ABSTRACT \\
\hline 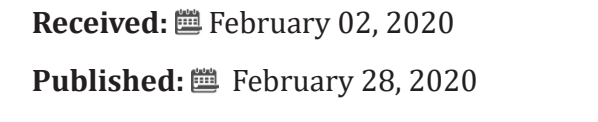 & $\begin{array}{l}\text { The principal aim of the present study was to probe the in vitro interactions of } \\
\text { Cefdinir with essential metal salt and antacid to determine the bioavailability in terms } \\
\text { of antimicrobial activity of Cefdinir after drug metal interactions at } \mathrm{pH} \text { 7.4. Cefdinir is a }\end{array}$ \\
\hline $\begin{array}{l}\text { Citation: Md Shahidul Islam, Md Abbul } \\
\text { Motaleb Bhuiya. Cefdinir with Antacid and } \\
\text { Metal Complexation and Investigation of } \\
\text { Antimicrobial Activity, In-Vitro Demonstra- } \\
\text { tion. Biomed J Sci \& Tech Res 26(1)-2020. } \\
\text { BJSTR. MS.ID.004292. } \\
\text { Keywords: Cefdinir; Interaction; Complex- } \\
\text { ation; Job's Plot; Antimicrobial Activity }\end{array}$ & $\begin{array}{l}\text { bacteria. Since the presence of compelling ligand may affect the bioavailability of a metal } \\
\text { in the blood or tissues, therefore in order to study the portable interaction of Cefdinir } \\
\text { with essential and trace elements present in the body. Cefdinir has been interacted with } \\
\mathrm{Zn} \text { (metal), Mg(antacid) as an in-vitro analysis. Also, the anti-microbial activity of the } \\
\text { drug and the complexes were determined. It has observed that Cefdinir interacts with } \\
\text { metal on a pH } 7.4 \text {, the stability constant of these complexes was determined in order } \\
\text { to evaluate their possible in vivo implications. This research work confirms that there } \\
\text { was a possible interaction between the Cefdinir and metal Zn and antacid Mg which was } \\
\text { confirms by jobs plot method and by antimicrobial investigation it was confirmed that } \\
\text { the zone of inhibition of Cefdinir with Metal Zn and antacid Mg reduced from } 16 \mathrm{~mm} \text { to } \\
13 \mathrm{~mm} \text { \& } 12 \mathrm{~mm} \text { respectfully. The standard Cefdinir disk also tested against Staphylococcus } \\
\text { aureus. In order to investigate the number of metal ions involved in the complexation } \\
\text { with Cefdinir complexes were elucidated by plotting various uv spectrophotometric } \\
\text { methods. }\end{array}$ \\
\hline
\end{tabular}

\section{Introduction}

A drug interaction can simply be defined as an interaction between a drug and any other substance that prevents the drug from performing as expected. A drug interaction is a situation in which a sub stance affects the activity of a drug when both are administered together. This action can be synergistic or antagonistic or a new effect can be produced that neither produces on its own. Typically, interactions between drugs come to mind. However, interactions may also exist between drugs and foods, as well as drugs and medicinal plants or herbs. People taking antidepressant drugs such as monoamine oxidize inhibitors should not take food containing tyramine as hypertensive crisis may occur. These interactions may occur out of accidental misuse or due to lack of knowledge about the active ingredients involved in the relevant substances [1]. Two drugs are antagonistic when their interaction causes a decrease in the effects of one or both of the drugs [2,3]. The different responses of a receptor to the action of a drug has resulted in a number of classifications, which use terms such as "partial agonist", "competitive agonist" etc. These concepts have fundamental applications in the pharmacodynamics of these interactions. The proliferation of existing classifications at this level, along with the fact that the exact reaction mechanisms for many drugs are not well understood means that it is almost impossible to offer a clear classification for these concepts. It is even likely that many authors would misapply any given classification [4] The important metal present in the body is iron which plays a central role in all living cells.

Generally iron complexes are used in the transport of oxygen in the blood and tissues [5]. An adult at rest consumes $250 \mathrm{ml}$ of pure oxygen per minute, this oxygen carried by the metal complex 
transport system known heame, alloying the oxygen to leave the blood when it reaches the tissue. The heame group is metal complex, with iron as central metal atom, which bind or released molecular oxygen [6]. Cephradine is a semisynthetic cephalosporin antibiotic developed at the Squibb Institute for Medical Research , chemically designed as 7-[D-2-amino-(1,4-cyclohexadiene-1-yl)acetamido]3-methyl-8-oxo-5-thia-1-azyabicyclo-octa-2-ene-2-carboxylic Acid or 7-[2-amino-2-(1,4-cyclohexadienyl)acetamido]-desacetylcephalosporanic acid [7]. It is defined as a hydrated form containing $3-6 \%$ of water, which is not a stoichiometric hydrate since the water moves freely in the crystal lattice [8]. Cephradine dihydrate, which crystallizes from aqueous solution under controlled conditions, is very stable and resistant to oxidation. However, on dehydration the dehydrate becomes very unstable. Cefdinir is used to treat pneumonia, strep throat, otitis media etc.

\section{Materials and Methods}

All the substances used here were analytical grade and were stored under sorted under optimum storage conditions (Tables 1 \& 2). Cefdinir solution $250 \mathrm{ml}$ of $1 \times 10^{-2} \mathrm{M}$ was prepared by dissolving $1.386 \mathrm{gm}$ of ceftriaxone in $250 \mathrm{ml}$ of demineralized water in a $250 \mathrm{ml}$ volumetric flask. The stock solution was diluted to desired strength by buffer solution.

Table 1: List of chemicals and reagents.

\begin{tabular}{|c|c|c|}
\hline Serial No & Name & Source \\
\hline 1 & Cefdinir & Gift samples from Incepta Ltd. \\
\hline 2 & Zinc Sulphate (Metal) & Merck ltd, Mumbai, India \\
\hline 3 & $\begin{array}{c}\text { Magnesium Hydroxide } \\
\text { (Antacid) }\end{array}$ & Merck ltd, Mumbai, India \\
\hline 5 & $\begin{array}{c}\text { Sodium di-hydrogen } \\
\text { phosphate }\end{array}$ & $\begin{array}{c}\text { USTC, Foys lake, Chittagong, } \\
\text { dept of pharmacy }\end{array}$ \\
\hline 5 & $\begin{array}{c}\text { Disodium hydrogen } \\
\text { phosphate }\end{array}$ & $\begin{array}{r}\text { USTC, Foys lake, Chittagong, } \\
\text { dept of pharmacy }\end{array}$ \\
\hline 6 & $\begin{array}{c}\text { Phosphate Buffer } \\
\text { pharmacy }\end{array}$ & $\begin{array}{r}\text { USTC, Foys lake, Chittagong, } \\
\text { dept of }\end{array}$ \\
\hline
\end{tabular}

Table 2: List of instruments \& Equipments.

\begin{tabular}{|c|c|c|}
\hline Name & Model & Source \\
\hline pH Meter & PH-211 & Hanna,Romania \\
\hline $\begin{array}{c}\text { UV } \\
\text { spectrophotometer }\end{array}$ & T80 & PG instrument Ltd, England \\
\hline Electronic Balance & AL-204 & Mettlertoleddo, Switzerland \\
\hline Pipette & & Fischer scientific,Germany \\
\hline
\end{tabular}

\section{Preparation of Metal Solutions}

For the preparation of $0.01 \mathrm{M}$ metal solution, zinc sulfate hepta hydrate $(0.28754 \mathrm{gm})$ was weighed accurately and introduced with the help of funnel in $100 \mathrm{ml}$ volumetric flask separately, dissolved in demineralized water and make up to the mark with the same solvent. These primary solutions were further diluted ten folds in the same solvent and the final solutions were $0.0001 \mathrm{M}$ concentration.

\section{Preparation of Antacid Solutions}

For the preparation of $0.01 \mathrm{M}$ antacid solution, magnesium hydroxide $(0.0740 \mathrm{gm})$ was weighed accurately and introduced with the help of funnel in $100 \mathrm{ml}$ volumetric flask separately, dissolved in demineralized water and make up to the mark with the same solvent. These primary solutions were further diluted ten folds in the same solvent and the final solutions were $0.0001 \mathrm{M}$ concentration.

\section{Preparation of Buffer Solutionstable}

To prepare buffer solution 1.76gm of disodium hydrogen phosphate was dissolved in demineralized water with $2.43 \mathrm{gm}$ of solution dihydrogen phosphate and $\mathrm{pH}$ was adjusted to 7.4 and the volume was made to $1000 \mathrm{ml}$ with the same solution.

\section{Preparation of Standard Curve of Cefdinir}

Cefdinir stock solution at $\mathrm{pH} 7.4$ and concentration of $1 \times 10$ ${ }^{5} \mathrm{M}$ was added in different concentrations to ten test tubes, to have the following concentrations: $9 \times 10^{-5} \mathrm{M}, 8 \times 10^{-5} \mathrm{M}, 7 \times 10^{-5} \mathrm{M}, 6 \times 10^{-5} \mathrm{M}$, $5 \times 10^{-5} \mathrm{M}, 4 \times 10^{-5} \mathrm{M}, 3 \times 10^{-5} \mathrm{M}, 2 \times 10^{-5} \mathrm{M}, 1 \times 10^{-5} \mathrm{M}$. The solutions were then properly mixed. The absorbance values of the solutions were determined at $262 \mathrm{~nm}$ by uv spectrometer. As a control of reference sample, phosphate buffer solution of pH 7.4 was used. The standard curve was obtained by plotting the absorbance of values against the corresponding concentrations.

\section{Disc Diffusion Method}

Solution of known concentration $(3 \mu \mathrm{g} / \mathrm{ml})$ of the test samples are made by dissolving measured amount of the samples in calculated volume of solvents. Dried and sterilized filter paper discs (6mm diameter) are then impregnated with known amounts of the test substances using micropipette [9]. Discs containing the test material are placed on nutrient agar medium uniformly seeded with the test microorganism, Standard antibiotic discs and blank discs are used as positive and negative control. These plates are then kept at low temperature $\left(4^{\circ} \mathrm{C}\right)$ for 24 hours to allow maximum diffusion. During this time dried discs absorb water from the surrounding media and then the test materials dissolve and diffuse out of the sample disc. The diffusion occurs according to the physical law that controls the diffusion of molecules through agar gel. As a result, there is a gradual change of test materials concentrations in the media surrounding the disc.

\section{Results and Discussion}

From the following Table 3, it can observe that the absorbance of Cefdinir increases with the increasing concentration according to Beer Lambert's Law (Table 4). From the Table 5, it can observe that the absorbance of Cefdinir is different when it interacts with $\mathrm{Mg}(\mathrm{OH})_{2}$. From the Table 6, it can observe that interaction between drug and metal may lead to form complexes which have different light absorption capacity and spectrum pattern is altered. So, any 
alteration and spectrum behavior is regarded as a tool for primary interaction from the spectral studies.

Table 3: Standard curve of Cefdinir.

\begin{tabular}{|c|c|}
\hline Mx10 $^{-5}$ & Absorbance \\
\hline 1 & 0.582 \\
\hline 2 & 0.594 \\
\hline 3 & 0.605 \\
\hline 4 & 0.609 \\
\hline 5 & 0.618 \\
\hline 6 & 0.628 \\
\hline 7 & 0.636 \\
\hline 8 & 0.643 \\
\hline 9 & 0.655 \\
\hline
\end{tabular}

Table 4: Absorbance of Cefdinir at different wavelength.

\begin{tabular}{|c|c|}
\hline Wavelength & Absorbance \\
\hline 200 & 0.134 \\
\hline 210 & 0.137 \\
\hline 220 & 0.223 \\
\hline 230 & 0.289 \\
\hline 240 & 0.109 \\
\hline 250 & 0.027 \\
\hline 260 & 0.005 \\
\hline 270 & 0.036 \\
\hline 280 & 0.021 \\
\hline 290 & -0.017 \\
\hline
\end{tabular}

Table 5: Spectral analysis of Cefdinir with $\mathrm{Mg}(\mathrm{OH})_{2}$.

\begin{tabular}{|c|c|c|}
\hline Wavelength/nm & $\begin{array}{c}\text { Absorbance of } \\
\text { Cefdinir }\end{array}$ & $\begin{array}{c}\text { Absorbance of Cefdinir + Mg } \\
(\mathbf{O H})_{\mathbf{2}}\end{array}$ \\
\hline 200 & 0.134 & 0.643 \\
\hline 210 & 0.137 & 0.876 \\
\hline
\end{tabular}

\begin{tabular}{|l|l|l|}
\hline 220 & 0.223 & 0.762 \\
\hline 230 & 0.289 & 0.422 \\
\hline 240 & 0.109 & 0.282 \\
\hline 250 & 0.027 & 0.092 \\
\hline
\end{tabular}

Table 6: Combined Spectral analysis of Cefdinir with $\mathrm{ZnSO}_{4} \cdot 7 \mathrm{H}_{2} \mathrm{O}$ and $\mathrm{Mg}(\mathrm{OH})_{2}$.

\begin{tabular}{|c|c|c|c|}
\hline $\begin{array}{c}\text { Wavelength/ } \\
\text { nm }\end{array}$ & $\begin{array}{l}\text { Absorbance } \\
\text { of Cefdinir }\end{array}$ & $\begin{array}{c}\text { Absorbance } \\
\text { of Cefdinir } \\
+\mathrm{ZnSO}_{4} \cdot \mathrm{H}_{2} \mathrm{O}\end{array}$ & $\begin{array}{c}\text { Absorbance of } \\
\text { Cefdinir +Mg } \\
(\mathrm{OH})_{2}\end{array}$ \\
\hline 200 & 0.134 & 0 & 0.643 \\
\hline 210 & 0.137 & 0.001 & 0.876 \\
\hline 220 & 0.223 & 0.071 & 0.762 \\
\hline 230 & 0.289 & 0.151 & 0.422 \\
\hline 240 & 0.109 & 0.063 & 0.282 \\
\hline 250 & 0.027 & 0.013 & 0.092 \\
\hline
\end{tabular}

\section{Effect of Metals on Ceftriaxone by Job's Method of}

\section{Continuous Variation}

The molar ratios of the complexes of Cefdinir with metal salts were estimated by Job's method. The observed absorbance values were measured in $\mathrm{pH} 7.4$ at various concentration $\left(1 \times 10^{-5}\right.$ to $9 \times 10^{-}$ ${ }^{5} \mathrm{M}$ ) of Cefdinir and metal salts. The Job's plots at $\mathrm{pH}$ were obtained by plotting absorbance difference against the mole fraction of the drug, Cefdinir which are presented in the following table (Table 7). From the above we can observe that Cefdinir forms strong 1:1 complex with zinc sulfate hepta hydrate which is indicated as inverted ' $V$ ' shaped curve. (Table 8) From the above we can observe that Cefdinir forms strong 1:1 complexes with $\mathrm{Mg}(\mathrm{OH})_{2}$ which is indicated as inverted ' $v$ ' shaped curve (Table 9).

Table 7: Values of job's plot of Cefdinir and $\mathrm{ZnSO}_{4} \cdot 7 \mathrm{H}_{2} \mathrm{O}$.

\begin{tabular}{|c|c|c|c|c|c|}
\hline $\begin{array}{l}\text { Concentration of } \\
\text { Cefdinir } \mathrm{Mx} 10^{-5}\end{array}$ & $\begin{array}{l}\text { Absorbance of } \\
\text { Cefdinir A }\end{array}$ & $\begin{array}{c}\text { Concentration of } \mathrm{ZnSO}_{4} \cdot 7 \mathrm{H}_{2} \mathrm{O} \\
\mathrm{Mx10}\end{array}$ & $\begin{array}{l}\text { Absorbance of } \\
\mathrm{ZnSO}_{4} \cdot 7 \mathrm{H}_{2} \mathrm{O}\end{array}$ & $\begin{array}{l}\text { Absorbance of } \\
\text { mixture C }\end{array}$ & $\begin{array}{c}\text { Absorbance difference } \\
D=(A+B)-C\end{array}$ \\
\hline 1 & 0.21 & 9 & 0.181 & 0.106 & 0.285 \\
\hline 2 & 0.217 & 8 & 0.18 & 0.105 & 0.292 \\
\hline 3 & 0.223 & 7 & 0.181 & 0.105 & 0.299 \\
\hline 4 & 0.231 & 6 & 0.181 & 0.108 & 0.304 \\
\hline 5 & 0.238 & 5 & 0.181 & 0.108 & 0.325 \\
\hline 6 & 0.243 & 4 & 0.188 & 0.11 & 0.321 \\
\hline 7 & 0.251 & 3 & 0.179 & 0.115 & 0.315 \\
\hline 8 & 0.257 & 2 & 0.177 & 0.114 & 0.314 \\
\hline 9 & 0.261 & 1 & 0.176 & 0.123 & 0.314 \\
\hline
\end{tabular}


Table 8: Values of Job plot of Cefdinir and $\mathrm{Mg}(\mathrm{OH})_{2}$.

\begin{tabular}{|c|c|c|c|c|c|}
\hline 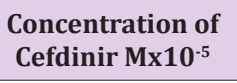 & $\begin{array}{l}\text { Absorbance of } \\
\text { Cefdinir A }\end{array}$ & $\begin{array}{c}\text { Concentration of } \mathrm{Mg}(\mathrm{OH})_{2} \\
\mathrm{Mx10}^{-5}\end{array}$ & $\begin{array}{l}\text { Absorbance of } \\
\mathrm{Mg}(\mathrm{OH})_{2} \text { B }\end{array}$ & $\begin{array}{l}\text { Absorbance of } \\
\text { mixture C }\end{array}$ & $\begin{array}{c}\text { Absorbance difference } \\
D=(A+B)-C\end{array}$ \\
\hline 1 & 0.21 & 9 & 0.086 & 0.108 & 0.188 \\
\hline 2 & 0.217 & 8 & 0.082 & 0.106 & 0.193 \\
\hline 3 & 0.223 & 7 & 0.089 & 0.112 & 0.2 \\
\hline 4 & 0.231 & 6 & 0.092 & 0.112 & 0.211 \\
\hline 5 & 0.238 & 5 & 0.099 & 0.115 & 0.222 \\
\hline 6 & 0.243 & 4 & 0.093 & 0.117 & 0.219 \\
\hline 7 & 0.251 & 3 & 0.084 & 0.117 & 0.218 \\
\hline 8 & 0.257 & 2 & 0.081 & 0.122 & 0.216 \\
\hline 9 & 0.261 & 1 & 0.079 & 0.126 & 0.214 \\
\hline
\end{tabular}

Table 9: Combined absorbance of drug with different metal \& antacid.

\begin{tabular}{|c|c|c|}
\hline Cefdinir & Cefdinir $+\mathbf{Z n S O}_{\mathbf{4}} \mathbf{.} \mathbf{7 H}_{\mathbf{2}} \mathbf{O}$ & Cefdinir $+\mathbf{M g}(\mathbf{O H})_{\mathbf{2}}$ \\
\hline 0.582 & 0.567 & 0.527 \\
\hline 0.594 & 0.577 & 0.531 \\
\hline 0.605 & 0.579 & 0.557 \\
\hline 0.609 & 0.573 & 0.565 \\
\hline 0.618 & 0.589 & 0.581 \\
\hline 0.628 & 0.57 & 0.524 \\
\hline 0.636 & 0.568 & 0.535 \\
\hline 0.643 & 0.564 & 0.537 \\
\hline 0.655 & 0.563 & 0.548 \\
\hline
\end{tabular}

\section{Antimicrobial Study}

The antimicrobial potency of the test agents is measured by their activity to prevent the growth of the microorganisms surrounding the discs which gives clear zone of inhibition. After incubation, the antimicrobial activities of the test materials were determined by measuring the diameter of the zones of inhibition in millimeter with a transparent millimeter scale. The test samples were tested against Staphyloccopcus aureus. The standard ceftriaxone disk also tested against Staphyloccopcus aureus. The results of the antimicrobial activity, measured in terms of diameter of zone of inhibition in $\mathrm{mm}$ are showed in table (Table 10). Antimicrobial sensitivity testing of Cefdinir against Staphylococcus aureus after interacting with $\mathrm{ZnSO}_{4} \cdot 7 \mathrm{H}_{2} \mathrm{O}$ and $\mathrm{Mg}(\mathrm{OH})_{2}$ solution respectively.

Table 10: Diameter of zone of inhibition.

\begin{tabular}{|c|c|c|}
\hline Bacteria used & $\begin{array}{c}\text { Standard disk (zone of } \\
\text { inhibition/mm) }\end{array}$ & $\begin{array}{c}\text { Sample disk (zone of } \\
\text { inhibition) }\end{array}$ \\
\hline $\begin{array}{c}\text { Staphylococcus } \\
\text { aureus }\end{array}$ & $16 \mathrm{~mm}$ & Cefdinir $+\mathrm{ZnSO}_{4} .7 \mathrm{H}_{2} \mathrm{O}$ \\
\hline $\begin{array}{c}\text { Staphylococcus } \\
\text { aureus }\end{array}$ & $16 \mathrm{~mm}$ & $13 \mathrm{~mm}$ \\
\hline & & $12 \mathrm{~mm}$ \\
\hline
\end{tabular}

\section{Conclusion}

In this present work, the interaction of an important antimicrobial drug, Cefdinir with Zinc Sulfate and antacid calcium hydroxide has been studied in the aqueous system at 7.4 by a variety of physical method like inspection of spectral behavior, Job's method of continuous variation by spectrophotometry. From this spectral study, it has been seen that Cefdinir gives a sharp peak at $262 \mathrm{~nm}$. When Zinc Sulfate and antacid solution, $\operatorname{Mg}(\mathrm{OH})_{2}$ mixed with Cefdinir wat 1:1 ratio, the intensity of the peak changes remarkably, i.e. absorption characteristics are altered due to interaction but the position of the compound do not shift. The antimicrobial screening of an agent is essential to ascertain its spectrum against various types of pathogenic organisms. The susceptibility of organism to antimicrobial agents can be measured in vitro by a number of techniques among which the disk diffusion method using different concentration of the agents absorbed on material filter paper disks, is widely acceptable for the preliminary evaluation of antimicrobial activity. Job's plot has given the molar ratio of complexes of Cefdinir and Zinc Sulfate, and antacid solution, $\mathrm{Mg}(\mathrm{OH})_{2}$. At pH 7.4 Cefdinir forms strong 1:1 complexes with Zinc Sulfate and antacid solution, $\mathrm{Mg}(\mathrm{OH})_{2}$ indicated as ' $\wedge$ ' shaped curves. These curves may indicate strong kinetics of complexation between Cefdinir with Zinc Sulfate and antacid solution, magnesium hydroxide. The test samples were tested against Staphylococcus aureus. The standard Cefdinir disk also tested against Staphylococcus aureus. It was observed that the antimicrobial activity of Cefdinir decreases when it forms complexes with $\mathrm{ZnSO}_{4} \cdot 7 \mathrm{H}_{2} \mathrm{O}$ and antacid solution, magnesium hydroxide. So, by antimicrobial investigation it was confirmed that the zone of inhibition of Cefdinir with Metals $\mathrm{Zn}$, Mg reduced from $16 \mathrm{~mm}$ to $13 \mathrm{~mm} \& 12 \mathrm{~mm}$ respectfully.

\section{References}

1. Koppisett SV, Chandra N (2011) Influence of Alcohol and Smoking on Drug Action: A Step for better utilization of drugs. Journal of Chemical and Pharmaceutical Research 3(1): 242-248.

2. Chou TC (2006) Theoretical basis, experimental design, and computerized simulation of synergism and antagonism in drug combination studies. Pharmacological reviews 58(3): 621-681. 
3. Sadowski D (2012) Drug Interactions with Antacids Mechanisms and Clinical Significance. springer international journal 11(6): 395-407.

4. Tallarida RJ (2001) Drug synergism: Its detection and applications Journal of Pharmacology and Experimental Therapeutics 298(3): 865872 .

5. Aronson JK (2004) Drug interactions-information, education, and the British National Formulary. British Journal of Clinical Pharmacology 57(4): 371-372.

6. Tunkel AR, Hartman BJ, Kaplan SL, Kaufman BA, Roos KL, et al. (2004) Practice guidelines for the management of bacterial meningitis. Clinical infectious diseases 39(9): 1267-1284.

ISSN: 2574-1241

DOI: $10.26717 /$ BJSTR.2020.26.004292

Md Shahidul Islam. Biomed J Sci \& Tech Res

(C) This work is licensed under Creative

Submission Link: https://biomedres.us/submit-manuscript.php
7. Moazzem hossen SM, Md Raihan Sarkar, Md Shahidul Islam, Abanti barua, Mohammad Kamal Hossain, et al. (2012) "In vitro interaction study of cephradine with dfferent essential mineral salts and its influence on antimicrobial acitiviity(MIC) of cephradine" International journal of pharmaceutical and life sciences 1:220-230.

8. Yawalkar N, Hari Y, Frutig K, Egli F, Wendland T, et al. (2000) T cells isolated from positive epicutaneous test reactions to amoxicillin and ceftriaxone are drug specific and cytotoxic. Journal of investigative dermatology 115(4): 647-652.

9. Jonathan Eldredge D (2003) The Randomised Controlled Trial design: unrecognized opportunities for health science librarianship", Health Information and Libraries Journal 20: 34-44.

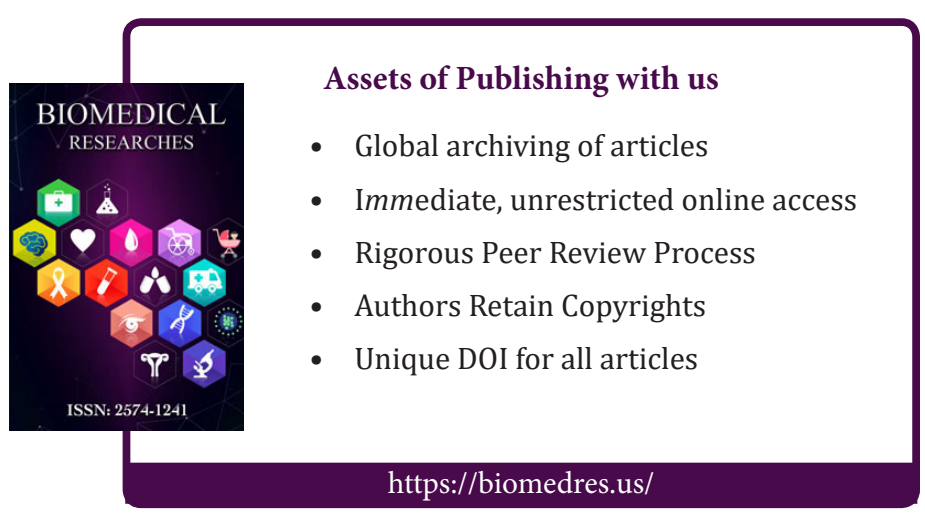

